\title{
Barbara Roggema. « Pour une lecture des dialogues islamo-chrétiens en syriaque à la lumière des controverses internes à l'islam »
}

\section{Christelle Jullien}

\author{
(2) OpenEdition \\ Journals \\ Édition électronique \\ URL : http://journals.openedition.org/abstractairanica/43983 \\ DOI : 10.4000/abstractairanica.43983 \\ ISBN : 1961-960X \\ ISSN : 1961-960X \\ Éditeur : \\ CNRS (UMR 7528 Mondes iraniens et indiens), Éditions de l'IFRI
}

\section{Référence électronique}

Christelle Jullien, « Barbara Roggema. « Pour une lecture des dialogues islamo-chrétiens en syriaque à la lumière des controverses internes à l'islam » », Abstracta Iranica [En ligne], Volume 37-38-39 | 2018, document 2, mis en ligne le 30 décembre 2018, consulté le 02 octobre 2020. URL : http://

journals.openedition.org/abstractairanica/43983; DOI : https://doi.org/10.4000/abstractairanica 43983

Ce document a été généré automatiquement le 2 octobre 2020.

Tous droits réservés 


\title{
Barbara Roggema. « Pour une lecture des dialogues islamo- chrétiens en syriaque à la lumière des controverses internes à l'islam »
}

\author{
Christelle Jullien
}

\section{RÉFÉRENCE}

Barbara Roggema. « Pour une lecture des dialogues islamo-chrétiens en syriaque à la lumière des controverses internes à l'islam » in Flavia Ruani (éd.). Les controverses religieuses en syriaque. Paris : Geuthner, 2016, p. 261-294, (Études syriaques 13).

1 L'A. s'interroge sur les thèmes des controverses islamo-chrétiennes, sur les aspects de l'islam qui furent condamnés, et sur les différences d'approches selon les époques, entre $\mathrm{VII}^{\mathrm{e}}$ et $\mathrm{XIII}{ }^{\mathrm{e}}$ siècle. Elle examine plus particulièrement la controverse du patriarche Timothée Ir avec le calife al-Mahdī, la discussion entre un musulman et un moine de Bēth-Ḥālē (est mentionnée à propos l'édition récente avec traduction commentée de D. Taylor, « The Disputation between a Muslim and a Monk of Bēt Hạalē: Syriac Text and annotated English Translation », dans S. H. Griffith et S. Grebenstein, Christsein in der islamischen Welt: Festschrift für Martin Tamcke zum 60. Geburtstag, Wiesbaden, 2015, p. 187-242), ou encore la polémique de Denys bar Șalībī contre la nation des Arabes, qui sont contextualisées par rapport aux débats contemporains du rédacteur. 


\section{AUTEURS}

\section{CHRISTELLE JULLIEN}

CNRS, Mondes iranien et indien, Paris 